\title{
Pengaruh Penggunaan Effective Microorganism 4 (EM4) Pada Budidaya Jamur Merang (Volvariella volvaceae) Menggunakan Media Tandan Kosong Kelapa Sawit.
}

\author{
Effect of Utilization Microorganism-4 (EM4) on Straw Mushroom \\ (Volvariella volvaceae) Cultivation Using Empty Palm Oil Fruit Bunch
}

\author{
Andriyanto $^{1 *}$, Retni S Budiarti ${ }^{2}$, Agus Subagyo $^{2)}$ \\ 1) Program Studi Pendidikan Biologi, STKIP YPM Bangko, Merangin, Jambi \\ 2) Program Studi Pendidikan Biologi Fakultas Keguruan dan Ilmu Pendidikan Universitas Jambi \\ Koresponden*: andriyanto@stkipypmbangko.ac.id
}

\begin{abstract}
Indonesia is the biggest producer of palm oil in the world. Palm oil empty fruit bunches is the biggest waste generated by the palm oil processing industry. However, utilization of the palm oil empty bunches has been not optimal. The palm oil empty fruit bunches have potential to be developed into a medium for growing mushroom because it has a high cellulose content. However, the high content of cellulose and lignin in palm oil empty fruit bunches is difficult to decompose into organic material that need for mushroom growth. The composting processes of empty fruit bunches can be increased by using Effective Microorganism (EM4). This study aims to understanding the role of Effective Microorganism 4 (EM4) on Volvariella volvaceae cultivation processes that used Empty Fruit Bunches compost. This research was conducted by composted the empty fruit bunch with different concentration of EM-4 there are 0\%,10\%, 15\%, $20 \%$ and $25 \%$. Parameters observed were number of mushrooms, weight of mushrooms and $\mathrm{C} / \mathrm{N}$ ratio of compost. The results showed that EM-4 had reduce $\mathrm{C} / \mathrm{N}$ ratio of empty bunch palm oil compost, $\mathrm{C} / \mathrm{N}$ ratio was not affected mushroom production and EM4 was affected mushroom production, the highest production reached by concentration of $15 \%$ that had not significant with concentration of $5 \%, 10 \%$ and $20 \%$. At concentration of $25 \%$ mushroom production was decreased. It is probably there are several mechanisms by EM4 microorganisms containing that affected mushrooms production.
\end{abstract}

Keywords: Empty Fruit Bunch, EM4, Volvariella volvaceae

\section{Pendahuluan}

Indonesia adalah produsen dan eksportir minyak sawit yang terbesar dunia (Suwandi, 2016). Kelapa sawit memiliki arti penting bagi pembangunan Indonesia karena dapat menciptaka lapangan kerja yang mengarah pada kesejahteraan masyarakat dan sebagai sumber devisa negara (GAPKI, 2018).

Berdasarkan data Direktoral Jendral Perkebunan, luas areal perkebunan kelapa sawit sampai tahun 2016 mencapai 33.229.381 Ha. Dari luas perkebunan kelapa sawit tersebut mampu menghasilkan 381 juta ton tandan buah segar (TBS). Tandan
Kosong Kelapa Sawit (TKKS) merupakan limbah padat terbesar yang dihasilkan oleh perkebunan kelapa sawit (PKS). Setiap pengolahan 1 ton TBS (Tandan Buah Segar) dihasilkan Tandan Kosong Kelapa Sawit (TKKS) sebanyak 22 - 23\% TKKS atau sebanyak 220 - 230 kg TKKS (Fuadi dkk., 2016). Namun, saat ini pemanfaatan TKKS belum optimal (Ngadi dan Lani, 2014).

Selama ini pemanfaatan limbah tandan kosong kelapa sawit sangat terbatas yaitu ditimbun (open dumping) dan dibakar dalam incinerator (Firmansyah, 2011). Salah satu alternatif penanganan limbah padat 
seperti TKKS adalah dengan mengubah limbah padat TKKS menjadi kompos.
Komposisi senyawa kimia penyusun TKKS (Tabel 1) antara lain selulosa, lignin, holoselulosa, hemiselulosa, air dan abu.

Tabel 1. Komposisi senyawa selulosa pada TKKS (Shinoj et al., 2011).

\begin{tabular}{cc}
\hline Komposisi & Kadar \\
\hline Selulosa (\%) & $42.7-65$ \\
\hline Lignin $(\%)$ & $13.2-25.32$ \\
\hline Hemiselulosa (\%) & $17.1-33.5$ \\
\hline Holoselulosa (\%) & $68.3-86.3$ \\
\hline Alfa selulosa (\%) & $41.9-60.6$ \\
\hline Kadar abu (\%) & $1.3-6.04$ \\
\hline
\end{tabular}

Kandungan selulosa yang tinggi pada TKKS memungkinkan kompos TKKS dimanfaatkan sebagai media tumbuh berbagai jenis jamur, salah satunya yaitu jamur merang (Wahyono, 2008). Namun, kandungan selulosa dan lignin pada TKKS yang tinggi menyebabkan waktu pengomposan TKKS hingga siap digunakan sebagai media tumbuh jamur merang memerlukan waktu yang cukup lama yaitu sekitar 6 minggu (Fadhilah dan Budiyanto, 2018). Oleh karena itu, upaya untuk mempercepat proses pengomposan TKKS sebagai media tumbuh jamur merang perlu dilakukan.

EM4 (Effective microorganism 4) dapat mempercepat proses pengomposan jerami padi dan sebagai media tumbuh jamur merang (Volvariella volvaceae). Menurut Andayanie (2013) pemberian EM4 dalam pengomposan media tanam dapat meningkatkan produksi jamur tiram putih (Pleurotus florida).

EM4 ditemukan oleh Prof. Teruo Higa dari Universitas Ryukyus Jepang. Larutan EM4 ini mengandung mikroorganisme fermentasi dan dapat bekerja secara efektif dalam mempercepat proses fermentasi pada bahan organik. Proses pembuatan kompos dengan menggunakan EM4 dapat lebih efektif dibandingkan dengan cara konvensional (Yuniwati dkk., 2012). Komposisi EM4 meliputi sekitar 80 genus mikroorganisme yang terdiri dari 5 golongan utama yaitu Bakteri pelarut fosfat, Lactobacillus, Yeast, Actinomycetes dan Bakteri Fotosintetik. Selain itu, EM4 memiliki kandungan unsur hara seperti $\mathrm{Ca}, \mathrm{Mg}, \mathrm{Fe}, \mathrm{Al}, \mathrm{Zn}, \mathrm{Cu}, \mathrm{Mn}$ dan $\mathrm{Na}$ (Subali dan Ellianawati, 2010).

Selain dapat mempercepat proses pengomposan, kandungan mikroorganisme di dalam EM4 dapat meningkatkan nutrient yang tersedia pada substrat. seperti Lactobacillus sp sebagai mikroorganisme utamanya, Bakteri fotosintetik seperti Rodhopseudomonas sp, berperan dalam fiksasi nitrogen (Sakpirom et al., 2019), Streptomyces sp berperan sebagai pendekomposisi substrat jamur merang (Fenandez et al., 2014). dan dapat menekan pertumbuhan jamur pathogen karena menghasilkan senyawa antibiotik (Cuppels et al., 2013). Keberadaan mikroorganisme tersebut dapat mendukung pertumbuhan jamur merang.

Penelitian ini bertujuan untuk (1) mengetahui pengaruh penambahan EM4 terhadap rasio $\mathrm{C} / \mathrm{N}$ kompos TKKS; (2) mengetahui hubungan antara rasio $\mathrm{C} / \mathrm{N}$ dengan produktivitas jamur merang; (3) mengetahui pengaruh penambahan EM4 terhadap produksi jamur.

\section{Metode Penelitian}

Penelitian ini dilaksanakan pada bulan Juli sampai September 2017 di usaha budidaya jamur Fisha Production Kecamatan Rimbo Bujang Kabupaten Tebo, Laboratorium Pendidikan Biologi STKIP YPM Bangko, Laboratorium Ilmu Tanah Fakultas Pertanian Universitas Jambi, dan Laboratorium Pendidikan Biologi Universitas Jambi. Penelitian menggunakan Rancangan Acak Lengkap (RAL) dengan perlakuan pemberian EM-4 pada saat pengomposan TKKS dengan konsentrasi 
$0 \%, 10 \%, 15 \%, 20 \%$ dan $25 \%$ dengan 3 ulangan.

Data dianalisis dengan menggunakan analisis sidik ragam dan jika terdapat perbedaan nyata dilanjutkan dengan uji Duncan New Multipe Range Test (DNMRT) pada taraf uji nyata $5 \%$.

\section{Alat}

Thermometer, higrometer, kumbung, autoclave, Labu semi-mikro Kjedal.

Bahan:

Limbah TKKS, bibit jamur merang, aktivator EM-4, dedak, kotoran ayam dan alkohol $70 \%$.

\section{Prosedur Kerja}

1. Pembuatan kumbung jamur berukuran $5 \mathrm{~m} \times 1,5 \mathrm{~m} \times 1 \mathrm{~m}$.

2. Pencacahan TKKS menjadi ukuran $\pm 5 \mathrm{~cm}$ sebanyak $30 \mathrm{Kg}$ untuk setiap perlakuan.

3. Pengomposan limbah TKKS menggunakan EM-4 dengan konsentrasi $0 \%, 10 \%, 15 \%, 20 \%$ dan $25 \%$ sebanyak 3 liter perpelakuan dan ditambahkan $7,5 \mathrm{~kg}$ dedak padi, 3 liter residu destileri.

4. Sterilisasi kompos TKKS menggunakan menggunakan autoclave.

5. Penanaman jamur merang sebanyak 75 gr bibit untuk setiap wadah $(1 \mathrm{~kg})$. Penaburan bibit jamur menunggu suhu turun, yaitu berkisar $35-40^{\circ} \mathrm{C}$.

6. Pemeliharaan jamur dan kumbung dilakukan penyiraman dan pengaturan suhu, Suhu ruangan pada waktu periode penanaman atau pertumbuhan jamur berkisar antara $30-35^{\circ} \mathrm{C}$.

7. Pemanenan jamur merang, dihitung jumlah jamur dan berat jamur untuk setiap perlakuan. Pada hari ke-10 setelah peletakan bibit, tubuh buah jamur merang stadia telur (egg stage) sudah dapat dipanen.

8. Analisis rasio $\mathrm{C} / \mathrm{N}$ kompos menggunakan metode Walkey and Black untuk analisis kandungan Karbon Organik (C) dan metode Kjedahl untuk analasis kandungan nitrogen $(\mathrm{N})$ (Suleman \& Eviati, 2007), pengukuran rasio $\mathrm{C} / \mathrm{N}$ dilakukan sebelum dan sesudah pemanenan jamur merang untuk mengetahui penggunaan bahan organik oleh jamur merang,

9. Analisis Data dengan menggunakan analisis sidik ragam dan uji Duncan New Multiple Range Test.

\section{Hasil dan Pembahasan}

Berdasarkan hasil penelitian, jamur merang mampu tumbuh pada kompos TKKS seperti yang ditunjukan pada Gambar 1 . Pertumbuhan jamur diawali dengan spora yang berkecambah membentuk hifa, selanjutnya hifa berkembang membentuk miselium yang menyebar pada permukaan media, miselium dari 2 strain yang berbeda (+ dan -) akan bersinggungan dan dinding selnya larut. Selanjutnya inti dari salah satu sel pindah ke sel yang lain sehingga terbentuk sel dengan 2 inti (dikariotik) selanjutnya dari sel dikariotik ini akan tumbuh menjadi tubuh buah (Gunawan, 2008).

Permanen jamur merang dilakukan pada hari ke 10 hingga hari ke 14 setelah penanaman bibit (Sunandar, 2010). Jumlah jamur merang tertera pada Tabel 1 sedangkan berat jamur tertera pada Tabel 2 .

Tabel 1. Jumlah jamur merang

\begin{tabular}{ccc}
\hline $\begin{array}{c}\text { Perlakuan } \\
\text { Konsentrasi EM-4 }\end{array}$ & $\begin{array}{c}\text { Rata-rata } \\
\text { Jumlah Jamur } \\
\text { (buah) }\end{array}$ & Notasi \\
\hline $0 \%$ & 21.4 & $\mathrm{a}$ \\
\hline $5 \%$ & 23 & $\mathrm{a}$ \\
\hline $10 \%$ & 25,6 & $\mathrm{a}$ \\
\hline $15 \%$ & 26 & $\mathrm{a}$ \\
\hline $20 \%$ & 22,8 & $\mathrm{a}$ \\
\hline $25 \%$ & 14,4 & $\mathrm{~b}$ \\
\hline
\end{tabular}


Tabel 2. Berat jamur merang

\begin{tabular}{ccc}
\hline Konsentrasi EM-4 & $\begin{array}{c}\text { Rata-rata } \\
\text { Jumlah Jamur (gr) }\end{array}$ & Notasi \\
\hline $0 \%$ & 165,74 & $\mathrm{a}$ \\
\hline $5 \%$ & 166,46 & $\mathrm{ab}$ \\
\hline $10 \%$ & 204,59 & $\mathrm{ab}$ \\
\hline $15 \%$ & 215,68 & $\mathrm{~b}$ \\
\hline $20 \%$ & 189,23 & $\mathrm{~b}$ \\
\hline $25 \%$ & 117,4 & $\mathrm{c}$ \\
\hline
\end{tabular}

Tabel 1 menunjukan jumlah rata-rata jamur merang tertinggi diperoleh pada konsentrasi $15 \%$ yaitu 26 jamur. Berdasarkan uji DNMRT EM4 tidak memberikah pengaruh signifikan terhadap jumlah jamur yang dihasilkan kecuali pada perlakuan konsentrasi EM4 25\%. Pada konsentrasi $25 \%$ diperoleh jumlah jamur terendah yaitu rata-rata 14,4 buah.

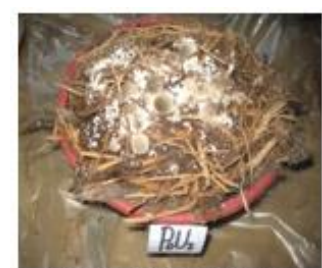

EM-4 kongentrasi 0\% (kontrol)

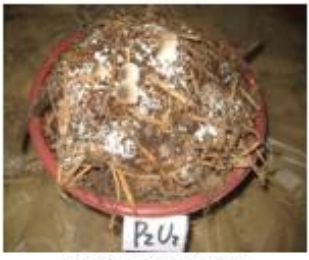

EM-4 konsentrasi $10 \%$

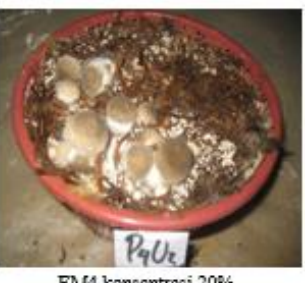

EM4 konsentrasi $20 \%$

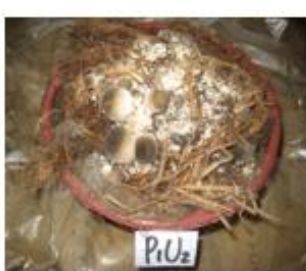

EM-4 konsentrasi 5\%

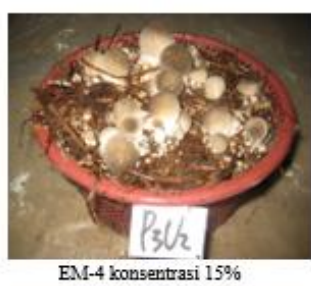

EM-4 konsentrasi $15 \%$

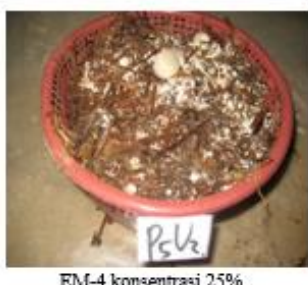

EM-4 konsentrasi $25 \%$

Gambar 1. Pertumbuhan jamur pada media

Jumlah dan berat jamur merang

Berdasarkan analisis sidik ragam EM4 berpengaruh terhadap berat jamur yang dihasilkan. Tabel 2 menunjukan berat produksi jamur merang tertinggi diperoleh pada konsentrasi $15 \%$ yaitu dengan rata-rata 215,68 gr, berdasarkan uji DNMRT konsentrasi $15 \%$ tidak berbeda nyata dengan perlakuan 5\%, 10\%, 20\%. Namun berbeda nyata jika dibandingkan dengan konsentrasi $0 \%$ dan $25 \%$. Rata-rata berat terendah diperoleh pada konsentrasi $25 \%$.
Pada konsentrasi 25\% baik jumlah jamur dan berat jamur yang dihasilkan lebih rendah dari perlakuan kontrol (konsentrasi $0 \%$ ). Hal ini kemungkinan disebabkan pada konsentrasi 25\% karbon dan nitrogen tidak dapat diserap dengan baik. Pada Tabel 3 dan 4 menunjukan bahwa pada konsentrasi $25 \%$ rasio karbon dan nitrogen $(\mathrm{C} / \mathrm{N})$ kompos awal adalah 18,95 dan rasio $\mathrm{C} / \mathrm{N}$ kompos akhir adalah 18,04 ., nilai rasio $\mathrm{C} / \mathrm{N}$ ini hanya berkurang sedikit. Rasio C/N kompos TKKS sebelum inokulasi bibit jamur ditunjukan 
pada Tabel 3 sedangkan setelah akhir masa pemanenan jamur ditunjukan pada Tabel 4.

Suatu bahan yang mengandung unsur $\mathrm{C}$ tinggi maka nilai $\mathrm{C} / \mathrm{N}$ rasionya akan tinggi, sebaliknya bahan yang mengandung unsur $\mathrm{N}$ yang tinggi nilai $\mathrm{C} / \mathrm{N}$ rasionya akan rendah (Purnawanto, A, G. dan Nugroho, B., 2015). Rasio $\mathrm{C} / \mathrm{N}$ merupakan salah satu parameter kematangan kompos. Nilai $\mathrm{C} / \mathrm{N}$ kompos yang semakin besar menunjukkan bahwa bahan organik belum terdekomposisi sempurna. Sebaliknya nilai $\mathrm{C} / \mathrm{N}$ kompos yang semakin rendah menunjukkan bahwa bahan organik sudah terdekomposisi dan hampir menjadi kompos (Ismayana dkk., 2012).

Tabel 3. Rasio C/N TKKS kompos awal (sebelum inokulasi bibit jamur)

\begin{tabular}{cccc}
\hline Konsentrasi EM4 & \multicolumn{3}{c}{ Kompos awal } \\
\cline { 2 - 4 } & $\mathrm{C}(\%)$ & $\mathrm{N}(\%)$ & $\mathrm{C} / \mathrm{N}$ \\
\hline $0 \%$ & 27,91 & 0,94 & 29,69 \\
\hline $5 \%$ & 30,06 & 1,93 & 15,57 \\
\hline $10 \%$ & 31,42 & 1,42 & 22,12 \\
\hline $15 \%$ & 29,96 & 1,68 & 17,83 \\
\hline $20 \%$ & 31,35 & 1,85 & 16,94 \\
\hline $25 \%$ & 31,42 & 1,69 & 18,59 \\
\hline
\end{tabular}

Tabel 4. Rasio C/N TKKS kompos akhir (setelah akhir masa panen jamur)

\begin{tabular}{cccc}
\hline Konsentrasi EM4 & \multicolumn{3}{c}{ Kompos akhir } \\
\cline { 2 - 4 } & $\mathrm{C}(\%)$ & $\mathrm{N}(\%)$ & $\mathrm{C} / \mathrm{N}$ \\
\hline $0 \%$ & 26,47 & 1,68 & 15,75 \\
\hline $5 \%$ & 29,86 & 1,77 & 16,78 \\
\hline $10 \%$ & 26,67 & 1,99 & 13,40 \\
\hline $15 \%$ & 26,63 & 1,81 & 14,71 \\
\hline $20 \%$ & 28,04 & 1,91 & 14,68 \\
\hline $25 \%$ & 29,41 & 1,63 & 18,04 \\
\hline
\end{tabular}

Pada Tabel 3 menunjukan bahwa rasio $\mathrm{C} / \mathrm{N}$ kompos awal relatif sama kecuali pada konsentrasi EM-4 0\% (kontrol) yaitu sebesar 29,69 yang lebih tinggi bila dibandingkan perlakuan lainnya. Hal ini disebabkan tidak adanya penambahan mikoorganisme yang mampu mendekomposisi TKKS sehingga proses pengomposan berjalan lambat. Selain rasio C/N kompos awal pada perlakuan konsentrasi EM4 0\%, rasio $\mathrm{C} / \mathrm{N}$ yang diperoleh secara keseluruhan lebih rendah bila dibandingkan dengan hasil penelitian Hayat \& Andayani, (2014) yang melakukan pengomposan TKKS, nilai $\mathrm{C} / \mathrm{N}$ rasio kompos TKKS yang diperoleh dari penelitian tersebut adalah 26,82\%.

Pada konsentrasi EM4 0\% penurunan rasio $\mathrm{C} / \mathrm{N}$ kompos awal dan akhir sebesar 13.94, paling tinggi dibandingkan pada perlakuan lainnya. Hal ini menjadi anomali mengingat data jumlah dan berat jamur pada perlakuan ini bukanlah yang tertinggi. Kemungkinan ini disebabkan oleh variasi data pada sampel perlakuan, mengingat untuk perhitungan rasio $\mathrm{C} / \mathrm{N}$ tidak dilakukan pengambilan sampel untuk setiap unit percobaan. Namun hanya diambil satu sampel untuk setiap perlakuan.

Secara umum terjadi penurunan rasio $\mathrm{C} / \mathrm{N}$ kompos setelah dilakukan penanaman jamur merang. Karbon dan nitrogen diserap jamur merang sebagai sumber nutrisi bagi pertumbuhan jamur merang sehingga mengakibatkan penurunan rasio $\mathrm{C} / \mathrm{N}$ pada media kompos akhir (setelah pemanenan jamur merang). Karbon (C) diperlukan untuk mendukung pertumbuhan miselium jamur. Kandungan C yang cukup tinggi pada media akan mempercepat pertumbuhan miselium sedangkan unsur $\mathrm{N}$ akan mendukung pembentukan tubuh buah 
(Chang \& Miles, 1989). Rasio C/N pada kompos awal dari setiap perlakuan masih memenuhi syarat tumbuh bagi jamur merang yaitu 24-36: 1 (Ekowati dan Risyanto dalam Yuliastrin, 2007). Selain itu menurut Wulan (2000) unsur karbon C merupakan unsur utama yang berperan dalam penyusunan sel. Unsur $\mathrm{N}$ memiliki peranan yang sangat penting dalam penyusunan asam nukleat, asam amino dan enzim-enzim.

Pada konsentrasi $0 \%$ rasio $\mathrm{C} / \mathrm{N}$ kompos awal paling tinggi dibandingkan dengan perlakukan lain. Hal ini menunjukan bahwa kandungan nitrogen pada kompos rendah. Bakteri fotosintetik seperti Rhodopesudomonas sp. yang terkandung dalam EM4 dapat membantu mengikat nitrogen karena memiliki enzim nitrogenase (Sakpirom et al., 2019) sehingga pada perlakuan lain nilai rasio $\mathrm{C} / \mathrm{N}$ kompos awal lebih rendah apabila dibandingkan dengan perlakuan konsentrasi EM4 0\%.

Mikroorganisme membutuhkan karbon dan nitrogen untuk aktivitas hidupnya. Jika rasio $\mathrm{C} / \mathrm{N}$ tinggi, aktivitas biologi mikroorganisme akan berkurang, diperlukan beberapa siklus mikroorganisme untuk mendegradasi kompos sehingga diperlukan waktu yang lama untuk pengomposan dan dihasilkan mutu yang lebih rendah, jika rasio $\mathrm{C} / \mathrm{N}$ terlalu rendah kelebihan nitrogen yang tidak dipakai oleh mikroorganisme tidak dapat diasimilasi dan akan hilang melalui volatisasi sebagai amoniak $\left(\mathrm{NH}_{3}\right)$ atau terdenitrifikasi (Tobing ,2009).

Mikoorganisme dalam EM-4 memiliki kemampuan untuk mendegradasi selulosa dan lignin pada TKKS. Berdasarkan hasil penelitian Wijana dan Mulyadi (2013) EM4 dapat menurunkan kadar lignin dan selulosa pada kulit buah dan pelepah tanaman nipah dengan lama waktu pemeraman selama 8 hari. Kadar lignin pada kulit buah nipah semula 27,3\% turun menjadi $11,90 \%$. Kadar lignin pada pelepah semula $19,85 \%$ turun menjadi $6,82 \%$. Kadar selulosa pada kulit buah semula 36,5\% turun menjadi $32,16 \%$. Kadar selulosa pada pelepah semula $42,22 \%$ turun menjadi $34,93 \%$.

Mikroorganisme yang berperan dalam mendegradasi lignoselulosa dalam EM4 adalah dari kelompok bakteri Actinomycetes terutama spesies Streptomyces sp karena memiliki enzim laccase (Fenandez et al., 2014). Enzim laccase dapat menguraikan struktur kristal senyawa lignin (Majumdar et al., 2014). Menurut Wei et al. (2019) inokulasi actinomycetes pada saat pengomposan mempercepat degradasi selulosa, hemiselulosa dan lignin, sebagai akibat meningkatnya aktivitas enzim-enzim kunci yang terlibat proses degradasi tersebut meliputi CMCase, Xylanase, manganase peroxidase, lignin peroxidase dan laccase.

Actynomycetes mendegradasi senyawa selulosa menjadi asam humat (Zao et al., 2017). Kandungan asam humat dalam kompos dapat meningkatkan produksi jamur. Hasil penelitian Prakash et al. (2010) menyatakan bahwa penambahan asam humat sebesar $4 \%$ pada kompos jerami padi mampu meningkatkan produksi jamur tiram (Pleurotus Ostreatus) dengan berat 242 gr, hasil yang lebih rendah diperoleh pada kompos dengan penambahan asam humat $1 \%$ dan $6 \%$ dengan produksi masing-masing sebesar 120 gr dan 96 gr. Hasil penelitian lain menyebutkan bahwa penambahan asam humat dan asam folat pada kompos mampu meningkatkan produksi jamur Agaricus bisporus, produksi terbaik diperoleh pada dosis $3 \mathrm{cc}$ perliter untuk asam folat dan 1,5 cc perliter untuk asam humat (Dahmardeh et al., 2015).

Tabel 4 menunjukan terjadinya penurunan rasio $\mathrm{C} / \mathrm{N}$ pada kompos akhir setelah pemanenan jamur merang. Penurunan rasio $\mathrm{C} / \mathrm{N}$ ini disebabkan terjadi dekomposisi bahan organik oleh jamur merang, sebab bahan organik merupakan sumber energi dan unsur hara bagi jasad hidup dalam proses asimilasi dan pembentukan selnya. Hasil akhir pelapukan menyebabkan kandungan C-organik dan rasio $\mathrm{C} / \mathrm{N}$ menurun sedangkan rasio $\mathrm{N}$ dan unsur lainnya meningkat (Suwastika dan Sutari, 2007).

Selain oleh aktivitas mikroorganisme yang terdapat dalam EM4, penurunan rasio $\mathrm{C} / \mathrm{N}$ juga diakibatkan oleh aktivitas Jamur Merang dalam mendegradasi TKKS karena memiliki Carbohydrate-Active Enzymes yaitu selulase, hemiselulase (Chem et al., 
2013) dan lignoselulase (Chang dan Stenkraus, 1982).

Beberapa hasil penelitian sebelumnya, dilaporkan bahwa TKKS dapat digunakan sebagai media tumbuh jamur merang. Purindaswari dkk. (2016) melaporkan bahwa penggunaan campuran 250 gr jerami ditambah 750 gr TKKS memberikan produksi jamur merang terbaik yaitu diameter jamur 2,23 cm, panjang jamur 7,15 $\mathrm{cm}$, jumlah buah 19 dengan berat 60,88 gr. Sementara itu hasil penelitian Fadhilah dan Budiyanto (2018), media tandan kosong kelapa sawit berumur 6 minggu dengan ketebalan media $20 \mathrm{~cm}$ memberikan produksi jamur terbaik dengan total berat jamur 238,8 gr.

Selain rasio $\mathrm{C} / \mathrm{N}$, faktor lain yang diduga mempengaruhi pertumbuhan jamur adalah $\mathrm{pH}$. Semakin tingginya konsentrasi EM4 yang diberikan saat pengomposan maka konsentrasi zat-zat hasil metabolisme mikoorganisme EM4 yang terakumulasi pada kompos juga semakin tinggi, salah satu zat yang terakumulasi tersebut adala asam laktat yang dihasilkan oleh Lactobacillus sp yang merupakan mikoorganisme utama dalam kultur campuran EM-4 dengan konsentrasi sebanyak $8,7 \quad \mathrm{x} \quad 10^{5}$ atau mencapai $90 \%$ dari populasi mikrobia pada EM-4 (Higa dan Kinjo, 1987). Akumulasi asam laktat menyebabkan $\mathrm{pH}$ media menjadi turun. Hal ini diduga menyebabkan pada kosnentrasi EM4 25\% produksi jamur menurun. Selain itu, penurunan ini diduga disebabkan tingginya kandungan asam humat sebagai hasil proses degradasi lignin oleh Actinomycetes. Hasil penelitian Prakash et al. (2010) menunjukan bahwa pemberian asam humat pada media budidaya jamur tiram sebesar 6\% memberikan produksi yang lebih rendah dibandingkan pemberian asam humat sebesar $1 \%$.

Hasil penelitian Rochaieni dkk. (2003) menunjukan bahwa pada awal proses pengomposan, derajat keasaman akan selalu turun karena sejumlah mikroorganisme tertentu akan mengubah bahan organik menjasi asam organik. Widodo dan Ashari (2009) juga menyatakan pada tahap awal fermentasi, asam organik dalam jumlah besar diproduksi oleh bakteri pembentuk asam sehingga $\mathrm{pH}$ dapat mencapai dibawah 5. Hal inilah yang kemungkinan menyebabkan produksi jamur pada konsentrasi EM-4 25\% turun.

Faktor lingkungan lain yang sangat berpengaruh terhadap pertumbuhan jamur merang adalah suhu dan kelembaban. Selama pengamatan suhu berkisar antara $26^{\circ}-32^{\circ} \mathrm{C}$ yang cukup ideal untuk pertumbuhan jamur merang. Kisaran suhu yang dibutuhkan untuk pertumbuhan jamur merang antara $30-35^{\circ} \mathrm{C}$ dan suhu paling sesuai adalah $32^{\circ} \mathrm{C}$ (Chang dan Miles, 1989).

Selama masa inkubasi, kelembaban cukup tinggi yaitu $83-91 \%$. Kisaran kelembaban tersebut cukup ideal untuk mendukung pertumbuhan jamur merang yaitu 85-90\% (Buswell dan Chen, 2005). Kelembaban sangan penting karena 89,42\% kandungan jamur merang adalah air (Rahmawati, 2016), sehingga berat jamur segar sangat ditentukan dari kelembaban media maupun kumbung.

\section{Kesimpulan}

Berdasarkan hasil penelitian yang telah dilaksanakan dapat disimpulkan bahwa, Penambahan EM4 dalam proses pengomposan dapat menurunkan rasio $\mathrm{C} / \mathrm{N}$ kompos TKKS. Sebelum inokulasi bibit jamur, rasio $\mathrm{C} / \mathrm{N}$ kompos kontrol (tanpa penambahan EM4) adalah 29,69 lebih tinggi jika dibandingkan dengan perlakuan penambahan EM4. Pada penelitian ini tidak terdapat hubungan antara nilai rasio $\mathrm{C} / \mathrm{N}$ dengan produksi jamur. Berdasarkan uji DNMRT penambahan EM4 berpengaruh terhadap produksi jamur. Konsentrasi EM4 $15 \%$ memberikan produktivitas jamur tertinggi, tidak berbeda nyata dengan perlakuan 5\%, 10\% dan 20\%. Pada konsentrasi $25 \%$ produktivitas jamur menurun.Pengaruh EM4 terhadap produksi jamur tidak hanya berkaitan penurunan rasio $\mathrm{C} / \mathrm{N}$. Kemungkinan terdapat mekanisme lain yang dilakukan oleh mikroorganisme yang terdapat pada EM4 seperti fiksasi nitrogen, aktivitas senyawa antibiotik dan adanya senyawa asam humat sebagai akibat proses dekomposisi senyawa lignoselulosa. Untuk mengetahui hal ini diperlukan penelitian lebih lanjut. 


\section{Ucapan Terimakasih}

Ucapan terima kasih ditujukan kepada Ibu Retni S.B, S.Pd., M.Si, Bapak Dr. Agus Subagyo, dan Owner Fisha Jamur Bapak Arwin dan Ibu Iba.

\section{Daftar Pustaka}

Andayanie, W.Y. 2013. Penambahan Em4 Dan Lama Pengomposan Media Tanam Terhadap Pertumbuhan Dan Hasil Jamur Tiram Putih (Pleurotus florida). Agri-tek 14(1): 33-41.

Busweell, J.A and Chen, M. 2005. Cultivation, Biochemical, Molecular Biological and Medical Aspect of the Culinary-Medicinal Straw Mushroom Volvariella volvaceae (Bull:Fr.) Singer (Agaricomycetideae). International Journal of Medicinal Mushrooms 7(1): 157-166.

Chang, S.C., and Steinkraus, K. H. 1982. Lignocellulolytic Enzymes Produced by Volvariella volvacea, the Edible Straw Mushroom. Applied And Environmental Microbiology 43(2): 440-446.

Chang, S.T and Miles, P.G. 1989. Edible Mushtooms and Their Cultivation. Boca Raton. CRC Press inc. Florida.

Chen, B., Gui, F., Xie, B., Deng, Y., Sun, X., Lin, M., tao, Y., and Li, S. 2013. Composition and Expression of Genes Encoding CarbohydrateActive Enzymes in the StrawDegrading Mushroom Volvariella volvacea. PLOS ONE 8(3): 1-9.

Cuppels, D.A., Higham, J., and Traquair, J.A. 2013. Efficacy of selected streptomycetes and a streptomycete + pseudomonad combination in the management of selected bacterial and fungal diseases of field tomatoes. Biological Control 67(3): 361-372.

Dahmardeh, M., Poodineh, Z., and Fakheri, B.A. 2015. Effects of Humic and Folic acid on Quantity and Quality Related Traits of Button Mushroom (Agaricus bisporus). Biological Forum - An International Journal 7(1): 823-828.
Dirjen Perkebunan. 2017 .Statistik Perkebunan Indonesia. Kementerian Pertanian. Jakarta.

Fadhilah, H. dan Budiyanto. 2018. Pengaruh Tandan Kosong Kelapa Sawit Sebagai Media Tumbuh Jamur Terhadap Produksi Dan Sifat Fisik Jamur Merang (Volvariella volvacea). Jurnal Agroindustri 8(1): 80-96.

Fernandes, T.A.R., da Silveira, W.B., Lopes Passos, F.M., Domingues Zucchi, T., 2014. Laccases from actinobacteriawhat we have and what to expect. Advance Microbioliology 4(1), 285296.

Firmansyah, A. M. 2011. Teknik Pembuatan Kompos. Kalimantan Tengah: Balai Pengkajian Teknologi Pertanian. P: 119.

Fuadi, A.M., dan Pranoto, H. 2016. Pemanfaatan Limbah Tandan Kosong Kelapa Sawit Sebagai Bahan Baku Pembuatan Glukosa. Chemica 3(1), 15.

Gapki. 2018. Refleksi Industri Kelapa Sawit. https://gapki.id/news/4140/refleksiindustri-kelapa-sawit-2017-danprospek-2018. 22 Maret 2019.

Gunawan, A.W. 2008. Usaha Pembibitan jamur. Penebar Swadaya. Jakarta.

Hayat, E. S., \& Andayani, S. 2014. Pengelolaan limbah tandan kosong kelapa sawit dan aplikasi biomassa chromolaena odorata terhadap pertumbuhan dan hasil tanaman padi serta sifat tanah sulfaquent. Jurnal Teknologi Pengelolaan Limbah 17(22): 44-51.

Higa, T. and Kinjo, S. 1987. Effect of Lactid Acid Fermentation Bacteria on Plant Growth and Soil Humus Formation. University of Ryukyus. Okinawa Japan.

Ismayana, A., Indrastim N.S., Suprihatin, Maddu, A., and Fredy, A. 2012. Faktor Rasio C/N Awal Dan Laju Aerasi Pada Proses Co-Composting Bagasse Dan Blotong. Jurnal Teknologi Industri Pertanian 22(3):173-179.

Majumdar, S., Lukk, T., Solbiati, J.O., Bauer, S., Nair, S.K., Cronan, J.E., Gerlt, J.A., 2014. Roles of small laccases from 
Streptomyces in lignin degradation. Biocehemistry 53(1), 4047-4058.

Ngadi, N., and Lani, N. S. 2014. Extraction and Characterization of Cellulose Acetate from Empty Friut Bunch (EFB) Fiber. Jurnal Teknologi 68(5): 35-39.

Prakash, P., Aashish, B.S., Neil, J.K., and Sivasubramnian. 2010. Effect of Humic Acid on Pleurotus Ostreatus Mushroom Cultivation and Analysis of Their Nutrient Contents. Research Journal of Agriculture and Biological Sciences 6(6). 1067-1070.

Purindaswari, R., Udiantoro., dan Agustina, L. 2016. Pemanfaatan Tandan Kosong Kelapa Sawit Sebagai Media Pertumbuhan Jamur Merang (Volvariella Volvaceae) Dalam Upaya Diversifikasi Pangan. Prosiding Seminar Nasional Lahan Basah Jilid 3: 908-912.

Purnawanto, A.M. dan Nugroho, B. Efektifitas Kompos Limbah Media Tanam Jamur Tiram Sebagai Pupuk Organik Pada Budidaya Bawang Merah Di Tanah Ultisol. Agritech 17(2): 97-105.

Rahmawati, N., Hasanuddin, dan Rosmayati. 2016. ABDIMAS TALENTA. Budidaya dan Pengolahan Jamur Merang (Volvariella volvaceae) dengan media limbah jerami. 1 (1): 58-63.

Rochaeni, A., Rusmaya, D. dan Hartini, P. 2003. Pengaruh Agitasi Terhadap Proses Pengomposan Sampah Organik. Infomatek 5(4): 177-186.

Sakpirom, J., Kantachote, D., Siripattanakul-Ratpukdi, S., McEvoy, J., and Khan, E. 2019. Simultaneous bioprecipitation of cadmium to cadmium sulfide nanoparticles and nitrogen fixation by Rhodopseudomonas palustris TN110. Chemosphere 223(1): 455-464.

Shinoj. S.P.S., Kochubabu, M., and Visvanathan, R. 2011. Oil palm fiber (OPF) and its composites: A review. Ind. Crops Productions 33(1). 7-22.

Subali, B dan Ellianawati. 2010. Pengaruh Waktu Pengomposan Terhadap Rasio Unsur $\mathrm{C} / \mathrm{N}$ dan Jumlah Kadar Air dalam Kompos. Prosiding Pertemuan Ilmiah XXIV Jateng dan DIY. 49-53.

Suleman dan Eviati. 2007. Analisis Kimia Tanah, Tanaman, Air, dan Pupuk. Balai Penelitian Tanah. Bogor.

Sunandar, B. 2010. Budidaya Jamur Merang. BPTP Jawa Barat. Kemeterian Pertanian: Bandung.

Suriawiria, U. 1986. Pengantar Untuk Mengenal dan Menanam Jamur. Angkasa. Bandung.

Suwandi. 2016. Outlook Kelapa Sawit. Komoditas Pertanian Subsektor Perkebunan. Jakarta: Pusat Data dan Sistem Informasi Pertanian Sekretariat Jenderal - Kementerian Pertanian. P:1.

Suwastika, A. A. A. G dan Sutari, N. W. 2007. Perlakuan Aktivator dan Masa Inkubasi Terhadap Pelapukan Limbah Jerami Padi. Jurusan Tanah Fakultas Pertanian Universitas Udayana. Denpasar.

Thomas L., Crawford D.L. 1998. Cloning of Clustered Streptomyces viridosporus T7A Lignocellulose. Canadian Journal of Microbiology 44(4):12-23.

Tobing, Esther L. 2009. Studi tentang kandungan Nitrogen, Karbon Corganik dan $\mathrm{C} / \mathrm{N}$ Dari Kompos Tumbuhan Kembang Bulan. Medan: Universitas Sumatera Utara

Wei, Y., Wu, D., Wei, D., Zhao, Y., Wu, J., Xie, X., Zhang, R., and Wei, Z. 2019. Improved lignocellulose-degrading performance during straw composting from diverse sources with actinomycetes inoculation by regulating the key enzyme activities. Bioresource Technology 271(1): 6674.

Widodo, T. W dan Asari, A. 2009. Teori dan Konstruksi Instalasi Biogas. Balai Besar Pengembangan Mekanisasi Pertanian Badan Litbang Pertanian, Departemen Pertanian. Serpong.

Wijana, S., dan Mulyadi, A.F. 2013. Pengaruh Lama Pemeraman Terhadap Kadar Lignin Dan Selulosa Pulp (Kulit Buah Dan Pelepah Nipah) Menggunakan Biodegradator EM4. Jurnal Industria 2(1): 75-83. 
Wulan, P.P.D.K., Gozan, M., Arby, B., dan Achmad, B. 2000. Penentuan rasio Optimum C:N:P sebagai nutrisi pada proses biodegradasi benzene-toluena dan scale up kolom bioregenerator. Departemen Teknik Kimia, Fakultas Teknik, Universitas Indonesia. Jakarta.

Yuliastrin, A. 2007. Pengaruh Penambahan Effective Microorganism-4 (EM-4) Pada Pengomposan Terhadap Produksi Jamur Merang. Jurnal Matematika, Sains \& Teknologi 8(2): 140-145.

Yuniwati, M., Iskarima, F., dan Padulemba, A. Optimasi Kondisi Proses Pembuatan Kompos Dari Sampah Organik Dengan Cara Fermentasi Menggunakan EM4. Jurnal Teknologi 5(2): 172-182.

Zhao, Y., Zhao, Y., Zhang, Z., Wei, Y., Wang, H., Lu, Q., Li, Y., and Wei, Z. 2017. Effect of thermo-tolerant actinomycetes inoculation on cellulose degradation and the formation of humic substances during composting. Waste Management 68(1): 64-73 